\title{
THE EFFECT OF MOODLE-MEDIATED INSTRUCTION ON THE READING COMPREHENSION OF IRANIAN EFL LEARNERS
}

\author{
Mahboube Rahmati Rad
}

M.A. Student of Translation at Islamic Azad University of Science and Research-Tehran, Iran

mahboobeh.raad69@gmail.com

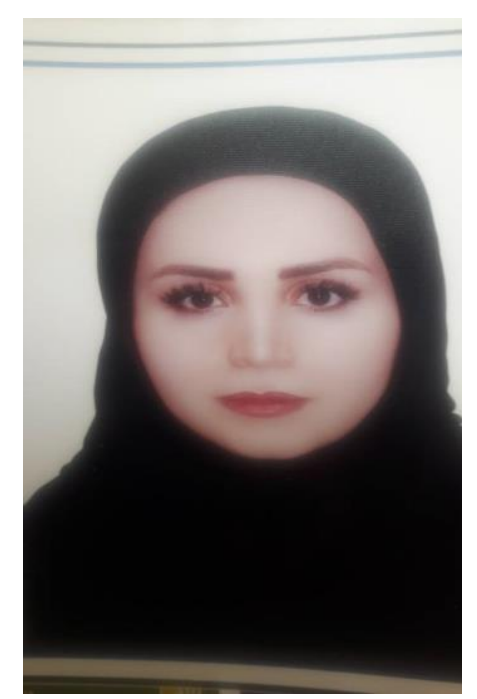

MAHBOUBE RAHMATI RAD

Keywords: EFL; E-learning; Moodle; reading comprehension

\begin{abstract}
A B S T R A C T
Web-based devices and applications which have the potential to increase the motivation and engagement of students to in language learning have attracted much attention among the ELT community. On the brand new web-based technological devices which have been employed for the educational purposes is the Moodle, an open source virtual learning environment. Given the significance of technology in general and the potentially influential role of the E-learning Moodle in second language learning, the present study investigates the effect of Moodle-mediated second language instruction on the reading comprehension of Iranian EFL students. In so doing, the EFL learners of two classes of English majors in an Islamic Azad university in Iran were recruited as the participants of the study. The students in the experimental group $(n=18)$ made use of blended learning in which Moodle was added to in-class instruction, whereas the learners in the control group $(n=21)$ were taught traditionally in which the learners just made use of in-class instruction. The experiment lasted for a period of one semester. The statistical analysis of the data revealed that the experimental group students outperformed those of the control group in terms of reading comprehension. The findings have significant implications for second language instruction.
\end{abstract}

Citation: Mahboube Rahmati Rad (2018). The Effect Of Moodle-Mediated Instruction On The Reading Comprehension Of Iranian EFL Learners. International Journal of Advanced Multidisciplinary Scientific Research (IJAMSR ) ISSN:2581-4281 Vol 1, Issue 3, May, 2018, \#Art.136, pp70-78

\section{Introduction}

Over the last decades, a significant number of educational centers, schools and institutes have eagerly seized upon course management systems (CMS) to improve teaching quality and effectiveness. Such are user-friendly and provide a variety of functions, such as saving and distributing teaching materials, recording and monitoring syllabi and learning activities, and evaluating both teaching and learning quality. The aforementioned functions are feasible tools, helping teachers to manage their courses more efficiently. Examples of CMSs consist of Blackboard, WebCT, eCollege, Moodle, Desire2Learn, Angel, etc., among which Moodle (Modular Object Oriented Developmental Learning Environment, Brandl, 2005; Cole, 2005; Robb, 2004) has been widely adopted throughout the world. Due to 


\section{International Journal of Advanced Multidisciplinary Scientific Research (IJAMSR) ISSN:2581-4281}

the perceived advantages of CMS, many educational centers have made remarkable investments and attempt in adopting instruments to encourage the integration of CMS into instruction in recent years (Carvalho, Areal, \& Silva, 2011). The very advantage of CMS may lie in the provision of adequate instructional time for teachers. The main stumbling block for teachers and practitioners is that there never seems to be sufficient time during a semester to cover all the material they intend to provide to the students. As a result, CMS provides a possible solution, which may help educators to create an online course that provides an opportunity for teachers and practitioners to interact with learners online. CMS provides the potentiality to inform students or to aid them in achieving better performance in specific learning activities in which they are willing to get involved. CMSs is able to enhance the learners' learning strategy use and self-regulated learning, since CMSs can encourage learners to build a new knowledge base by selecting and aligning their strategy use and their metacognitive (Winne \& Hadwin, 1998).

Concerning the effectiveness of CMS in language learning, Sanprasert (2009) investigated the effect of employing CMS on language learner autonomy in a study of Thai EFL learners who were divided into experimental (CMS use) and control groups (no CMS, but same learning materials). As the findings obtained from the quantitative analyses of pre-/post-course questionnaires and the qualitative analysis of learner journals revealed that CMS users became more autonomous and more confident learners, and that using CMS could help to develop a learner's sense of autonomy.

Similarly, in a case study to investigate WebCT uses for a graduate-level FL seminar, S. Carey (1999) described CMS as "the most significant innovation that I have experienced to improve the quality and depth of student involvement in a graduate seminar while promoting the students' improvement in academic reading comprehension and academic writing production" ( $\mathrm{p}$. 379).

On the other hand, with the advent of virtual teaching, computer-mediated communication (CMC) has been thought of as a critical means to recognize interactivity in virtual teaching and learning settings. CMC sets up a learning mechanism involving student-centered interaction which encourages learners to engage in an atmosphere of negotiation as well as raise socio-cultural awareness and foster cognitive development (Zhao \& Lai, 2008). Online-based activities in virtual settings can motivate learners to complete tasks more effectively via interactive and collaborative activities with others. CMS has also been acknowledged as a key component and process of language learning (Mercer, Fernandez, Dawes, Wegerif, \& Sams, 2003). CMC has the potentiality to encourage cognitive activities which enhance learner acquisition of language knowledge through interactive talk and scaffolding as championed by constructivism (Zhao \& Lai, 2008).

CMC creates a facilitating learning atmosphere since it possesses the characteristics of linguistic support and interaction to cultivate second language acquisition in L2 learners. Within CMC, learners interact to exchange ideas and share information. As far as second language acquisition is concerned, learners are able to produce target language output after being exposed to sufficient input. As a result, the virtual learning community can provide the learners with the opportunity to acquire a target language through receiving input from others, scaffolding that helps them to enhance their own language competencies.

Numerous potential benefits from the CMC use in language learning have been pointed out in the literature. For instance, according to Davis and Thiede (2000), the use of authentic communication via written English in $\mathrm{CMC}$ is popular in the writing research field. More specifically, online networks can create a multicultural environment in which the language learners are engaged in both creative and interactive writing. Making use of text-based forms to interact with partners and through peer-response activities in an online environment, learners are given a new chance to enhance their writing development (Shudooh, 2003). Getting engaged in an online environment, language learners become motivated to use the target language to write by making use of active thinking instead of memory and to think about the main points in the content (Brain, 2008). As far as L2 writing is concerned, receiving others' feedback in the online environment also encourage and help learners to construct their pieces of written through revising drafts and making corrections thereby 


\section{International Journal of Advanced Multidisciplinary Scientific Research (IJAMSR) ISSN:2581-4281}

increasing self-efficacy and motivation in L2 writing (Shudooh, 2003). Additionally, CMC can establish a non-threatening learning environment because the online environment provides learners with more time to prepare content and consider responses carefully before they compose. As a result, CMC aids learners in developing language learning while reducing psychological barriers. Moreover, appropriate employment of CMC has been reported to promote English writing in the areas of grammar (Salaberry, 2001), pragmatics, and communicative competence (Zhao \& Lai, 2008).

\section{Moodle}

Moodle, which stands for Modular Object-Oriented Dynamic Learning Environment, a free and open-source e-learning software was developed by Marin Dougiamas in 2004. This software is also known as a Course Management System (CMS), a Learning Management System (LMS), or a Virtual Learning Environment (VLE). Moodle software is contingent upon the concepts of social constructivism, providing both educators and students with a platform for online interaction and collaboration. This software is more appropriate for teaching and instruction because it can provide various teaching activities for students, give students the advantage of modern network technology to exchange ideas and obtain learning experience, and build personal knowledge system. The predominant advantage of the system may be the potentiality of effective integration of different kinds of teaching activities in the instruction so that the students can take advantage of productive functions of Moodle, such as chat rooms, forums, Webquest and Wiki, to do collaborative learning, that is able to convert the traditional closed learning environment into an open interactive network learning platform.

Moodle is thought to be the world's most popular Learning Management System (LMS) for both learning and teaching in a variety of fields, since it is userfriendly, open source, and free to download (Lambda Solutions, 2017). Moodle can enhance the quality of traditional, inside-the-class instruction through offering opportunities for further learning and teacher feedback outside the boundaries of the classroom (Al-Busaidi \& Al-Shihi, 2010; Coskun \& Arslan, 2014; Soliman, 2014).

As far as foreign language learning is concerned, Moodle is claimed to be an effective vehicle and is able to help learners develop their general language skills, pronunciation, vocabulary, and grammar (Levy, 2009; Lin, 2009). Moreover, Moodle can be also effective for teachers since it helps teachers manage their courses and communicate, both synchronously and asynchronously, with their learners (Wu, 2008). More specifically, Moodle has been reported to be effective in enhancing the general proficiency of EFL learners and has contributed to fostering the L2 reading comprehension and grammar performance (Hung \& Lin, 2014; Plomteux, 2013).

Various studies employing computer-mediated texts with glossaries have revealed the positive role of electronic glossaries in enhancing vocabulary learning or reading comprehension.

Bataineh and Mayyas (2017) for example investigated the effectiveness of Moodle-enhanced instruction on Jordanian EFL students' reading comprehension and grammar performance. They employed a quasiexperimental, pre-/post-test design in which a sample of students in a language requirement course at a Jordanian state university was recruited and randomly divided into an experimental group and a control group. The experimental group used blended learning in which Moodle supplemented in-class instruction. The analysis of the data revealed that the experimental group outperformed the control group in terms of both reading comprehension and grammar.

In another study conducted by Ayan (2015), the role of Moodle as a device to motivate and create autonomous e-learning in English language courses in Turkey was investigated. The participants were the EFL learners who had not attended any English preparatory class at the university level and had never used a particular learning management system for learning English before. To accomplish the purpose of the study, the students made use of Moodle to learn and improve their English with asynchronous applications as an extra instruction to face-to-face sessions of the courses. After four months of study, mean scores of their exam scores and a satisfaction scale were administered to evaluate the effectiveness of Moodle on students' motivations and autonomous learning. The findings of the study indicated that Moodle increased the levels of the students' motivation and autonomy to improve their English language skills. 


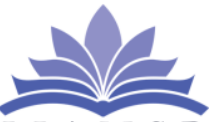

I J A M S R

\section{International Journal of}

In the same vein, Reinking and Rickman (1990) examined if intermediate-level readers' vocabulary learning and comprehension can be enhanced by displaying text on a computer screen that provided the meanings of difficult words. The results revealed that learners who read texts with computer assistance outperformed on a vocabulary test, and learners who read texts on the computer screen with mandatory assistance also scored higher than other learners on a reading comprehension test. The conclusion of the study was that reading comprehension can be fostered when computer-mediated texts are employed.

Given the significance of course management systems and online communication in language learning, the main research question of this study is:

Does Moodle-mediated instruction have any significant effect on the reading comprehension of Iranian EFL learners?

\section{Method}

\section{Participants}

The participants of this study were a sample $(n=39)$ of intermediate Iranian EFL students. They were all English major students studying either English literature or English translation at a branch of Islamic Azad University in Tehran, Iran. The students were both male and female who aged 19 to 24 with the average age of 20.48. The participants of the present study were required to take a four-credit reading course offered to the students of both majors at the bachelor's program. The participants of the study were students of two preexisting classes. To compensate for random selection and to provide some control over the internal validity threats, the two groups were randomly assigned to treatment and control group (Ary, Jacobs, \& Razavieh, 1990). One of the classes $(n=18)$ was considered as the experimental group, and the other class $(n=21)$ served as the control group. The students in the experimental group made use of blended learning in which Moodle was added to in-class instruction, whereas the learners in the control group were taught traditionally in which the learners just made use of in-class instruction. The experiment lasted for a period of one semester. Prior to the conduction of the treatment, the proficiency test which was the Oxford Quick Placement Tests (QPT) was administered to all the participants. The reason for the administration of proficiency test was the fact that English language proficiency was regarded as a relevant variable affecting the reading performance of the participants. After the administration of the QPT, an independent-samples t-test was conducted to explore the difference between groups. The result of the independent-samples t-test indicated that the groups had no statistically significant difference before the conduction of the treatment.

\section{Instruments}

In order to investigate the homogeneity of the participants, the QPT was utilized. It is a flexible test of English language proficiency developed by Oxford University Press and Cambridge ESOL that gives teachers a reliable and time-saving method of finding a student's level of English. It is quick and easy to administer and is ideal for placement testing and examination screening. The test has two parallel versions, and takes approximately 60 minutes to administer.

All the questions on the test are in multiple-choice format; answers are recorded directly on the answer sheet; and the answer sheets can be quickly marked using the overlays provided. The test measures the knowledge of English structure, and also is considered as a global measure of ability in a language or other content areas. In order to have a homogenous group of participants, those learners whose scores were at the intermediate level were selected to take part in the study. The test enjoys high reliability $(\alpha=.91)$ as measured by Cronbach's alpha (Berthold, 2011, p. 674). The test has been also reported to enjoy high construct validity (Wistner, Sakai, \& Abe, 2009).

\section{Reading Comprehension Test}

In order to measure the reading comprehension ability of the participants, a 40 item multiple-choice reading test was developed, piloted with 30 students with similar features to those of the main participants of the study, and administered to the participants of both groups. The test was developed based on the learners' course book. This teacher-made developed test served as both pre-test and post-test to measure the reading comprehension performance of the students. 


\section{International Journal of Advanced Multidisciplinary Scientific Research (IJAMSR) ISSN:2581-4281}

\section{Procedure}

The two groups of the students were taught by the same instructor who covered the same book for the two groups. The teacher was supposed to cover some units pre-determined by the institute for the period of the semester. Moreover, for the purpose of the present study, the researcher also provided the students of the experimental group with adequate access to Moodle inside and outside the classroom. The classes were held three times per week and each session lasted for 90 minutes. For both classes, the teacher first made attempts to arouse the interest of the students on the topic and also activated the students' relevant schema of the texts. In addition, he explained the meanings of the unfamiliar words to the students. Then, the teacher reads the paragraphs of the text one by one and elaborated on the meaning of the paragraphs in details. Afterwards, the students of both groups were required to answer the questions and exercises in pairs. To check the comprehension of the texts, the instructor usually asked further questions as well.

For the specific purpose of the treatment, the teacher provided the students of the experimental group with a Moodle tutorial. The experimental group students were trained to regularly view the material posted on Moodle during each week over the course of the treatment. The students were informed of the fact that the Moodle materials are supplementary to reading comprehension instruction. The teacher was also available for any guidance and technical support. He also checked the Moodle to answer the questions, make comments on forums, and evaluate students' other Moodle-related activities on a daily basis. The less active students were also encouraged to have more participation. The experimental group was also provided with covered content posted on Moodle to supplement in-class classroom instruction.

\section{Data Analysis}

In order to answer the research question, the mean scores of the control and experimental groups were compared and also a statistical analysis of one-way ANCOVA was used to test possible differences between the two groups at the beginning and end of the study. This was done to see if there was any significant difference between the performance of the control and experimental group on the pre-test and post-test of the study.

\section{Result}

During the data analysis to answer the research question, first the normality of the distribution of the scores was investigated. To check the normality assumption, one-sample KolmogorovSmirnov (K-S) test was run on both pre-test and post-test scores. In one-sample KolmogorovSmirnov (K-S) test, if the significance level is larger than.05, it shows that the data are normally distributed. As it is seen in Table 1., the results of one-sample K-S test indicated that the data was normally distributed.

Table 1. One-Sample Kolmogorov-Smirnov Test

\begin{tabular}{|c|c|c|c|}
\hline & & pre & Post \\
\hline \multicolumn{2}{|l|}{$N$} & & \\
\hline \multirow[t]{2}{*}{ Normal parameters } & Mean & 35.1282 & 39.9744 \\
\hline & $\begin{array}{l}\text { Std. } \\
\text { Deviation }\end{array}$ & 9.87069 & $1.14144 \mathrm{E} 1$ \\
\hline \multirow{3}{*}{$\begin{array}{c}\text { Most Extreme } \\
\text { Differences }\end{array}$} & Absolute & .160 & .122 \\
\hline & Positive & .160 & .122 \\
\hline & Negative & -.101 & -.070 \\
\hline \multicolumn{2}{|c|}{ Kolmogorov-Smirnov $Z$} & .998 & .761 \\
\hline \multicolumn{2}{|c|}{ Asymp. Sig. (2-tailed) } & .272 & .608 \\
\hline
\end{tabular}

Then, to answer the research question of the study, which addressed the effectiveness of Moodle-mediated L2 reading instruction in enhancing reading comprehension performance of Iranian EFL learners, an ANCOVA was run. According to Pallant (2007), ANCOVA can be used when there is a pre-test/post-test design. The scores on the pre-test are treated as a covariate to 'control' for pre-existing differences between the groups. 


\section{International Journal of} Advanced Multidisciplinary Scientific Research (IJAMSR) ISSN:2581-4281

To run ANCOVA, one important assumption is the homogeneity of regression slopes which must be met first. This assumption deals with the relationship between the covariate and the dependent variable for each of the groups (Pallant, 2007). It should be checked that there is no interaction between the covariate and the treatment or experimental intervention. Table 2 reveals that this assumption has not been violated; If the Sig. The level of the interaction is less than or equal to.05, the interaction is statistically significant, indicating that the assumption has been violated. As the table indicates the Sig. level for group * pretest is .854 , suggesting that this assumption has not been violated.

Table 2. Homogeneity of regression slopes

\begin{tabular}{|c|c|c|c|c|c|c|}
\hline Source & $\begin{array}{lr}\text { Type } & \text { III } \\
\text { Sum } & \text { of } \\
\text { Squares } & \end{array}$ & Df & $\begin{array}{l}\text { Mean } \\
\text { Square }\end{array}$ & $F$ & Sig. & $\begin{array}{l}\text { Partial } \\
\text { Eta } \\
\text { Squared }\end{array}$ \\
\hline $\begin{array}{l}\text { Corrected } \\
\text { Model }\end{array}$ & $4147.215^{\mathrm{a}}$ & 3 & $\begin{array}{l}1382.40 \\
5\end{array}$ & $\begin{array}{l}60.19 \\
7\end{array}$ & .000 & .838 \\
\hline Intercept & 97.473 & 1 & 97.473 & 4.245 & .047 & .108 \\
\hline Group & 53.135 & 1 & 53.135 & 2.314 & .137 & .062 \\
\hline Pre & 3537.814 & 1 & $\begin{array}{l}3537.81 \\
4\end{array}$ & $\begin{array}{l}154.0 \\
55\end{array}$ & .000 & .815 \\
\hline $\begin{array}{l}\text { group * * } \\
\text { pre }\end{array}$ & .785 & 1 & .785 & .034 & .854 & .001 \\
\hline Error & 803.760 & 35 & 22.965 & & & \\
\hline Total & 67271.000 & 39 & & & & \\
\hline $\begin{array}{l}\text { Corrected } \\
\text { Total }\end{array}$ & 4950.974 & 38 & & & & \\
\hline
\end{tabular}

Afterwards, a one-way between-group analysis of covariance was conducted to investigate the effectiveness of the intervention which was Moodlemediated instruction on the reading comprehension of Iranian EFL students.. Participants' scores on the pre-test were used as the covariate in this analysis.
Preliminary checks were conducted to ensure that there was no violation of the assumptions of normality, linearity, homogeneity of variances, homogeneity of regression slopes, and reliable measurement of the covariate. After adjusting for pre-intervention scores, as the Table 3 indicates that there was a significant difference between the control and the experimental groups on post-intervention scores on the reading test, $F$ $(1,36)=25.832, P=.000$, partial eta squared $=.41$. 


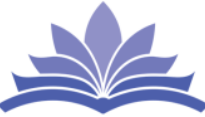

I J A M S R

\section{International Journal of}

Advanced Multidisciplinary Scientific Research (IJAMSR) ISSN:2581-4281

Table 3. ANCOVA results

\begin{tabular}{|c|c|c|c|c|c|c|}
\hline Source & $\begin{array}{c}\text { Type III Sum } \\
\text { of Squares }\end{array}$ & $\mathrm{df}$ & $\begin{array}{l}\text { Mean } \\
\text { Square }\end{array}$ & F & Sig. & $\begin{array}{r}\text { Partial Eta } \\
\text { Squared }\end{array}$ \\
\hline $\begin{array}{c}\text { Corrected } \\
\text { Model }\end{array}$ & $4146.430^{\mathrm{a}}$ & 2 & $\begin{array}{c}2073.21 \\
5\end{array}$ & $\begin{array}{c}92.76 \\
8\end{array}$ & $\begin{array}{l}.00 \\
0\end{array}$ & .837 \\
\hline Intercept & 97.056 & 1 & 97.056 & 4.343 & $\begin{array}{c}.04 \\
4\end{array}$ & .108 \\
\hline Pre & 3543.233 & 1 & $\begin{array}{c}3543.23 \\
3\end{array}$ & $\begin{array}{c}158.5 \\
45\end{array}$ & $\begin{array}{c}.00 \\
0\end{array}$ & .815 \\
\hline Group & 577.312 & 1 & 577.312 & $\begin{array}{c}25.83 \\
2\end{array}$ & $\begin{array}{c}.00 \\
0\end{array}$ & .418 \\
\hline Error & 804.545 & 36 & 22.348 & & & \\
\hline Total & 67271.000 & 39 & & & & \\
\hline $\begin{array}{c}\text { Corrected } \\
\text { Total }\end{array}$ & 4950.974 & 38 & & & & \\
\hline
\end{tabular}

\section{Discussion and Conclusion}

The main purpose of the study was to investigate the effectiveness of Moodle on the reading comprehension of Iranian EFL students. The collected data from the quasi-experimental design revealed that the students who underwent the Moodle-mediated instruction outperformed the students of the control group who were taught based on the regular, traditional method. The better performance of the experimental group in reading comprehension may be justified because of the fact that the experimental group students were more engaged in learning and self-assessment.

The slides may have contributed a lot to the reading comprehension improvement. The necessary information and knowledge about the reading, how to answer the questions, and answer keys were presented on the slides. The students could have access to further practice through hyperlinks, to similar exercises on the web. They were also provided with self-assessment tests periodically. The finding of the present study chime with that of Bataineh and Mayyas (2017) who emphasized the role of self-assessment activities in Moodle-supported language instruction. The fast feedback provided by Moodle reduced learning time and enhanced the confidence of learners thereby fostering reading comprehension. Self-assessment led to more engagement of the learners so that the learners took the responsibility of their own learning.

As revealed by previous studies (Boers, Eyckmans, \& Stengers, 2004; Abraham, 2008), it can be argued that computer mediated text glosses provide lexical support on comprehending authentic second language readings and learning vocabulary. From this perspective, electronic glossing is widely appreciated as an appropriate method for helping learners while read academic texts in a foreign language (Nation, 2001). The finding of the current study re-emphasizes the fact that being exposed to web-based language learning will significantly enhance language learning (Zhang \& Wu, 2008). More specifically, the results of the present study chime with those of Dreyer and Nel (2003), Tsai and Talley (2014), Sun (2014), and Banditvilai (2016), all reporting the influential role of Moodle and online learning in improving reading comprehension.

As far as the implications of the study are concerned, one use of the findings of the present study might be the suggestion that both language practitioners and language learners should be both trained to make use of Moodle technology in their own classes. In addition, the institutes and language centers should be equipped with required technological infrastructure.

Similarly, from the pedagogical and practical perspective, the present study suggests that ELT policy makers, practitioners, methodologists, and textbook developers should pay serious attention to initiatives by which more technological and web-based devices can be integrated in second language classes. Over the few past decades, methods of teaching and the means of learning have undergone drastic changes because of the emergence of information technology and computer. 


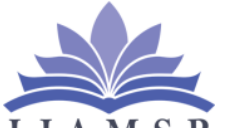

I J A M S R

\section{International Journal of}

Advanced Multidisciplinary Scientific Research (IJAMSR) ISSN:2581-4281

With the increased access to information and its vast spread, the new generation of learners has been provided the opportunity to access computers and the internet to gain knowledge without the time and space limitation, thereby making them have more autonomy and flexibility to choose their own preferred content and methodology of learning. As a result, the traditional teacher-centered teaching methods are no longer welcomed by the young learners of the today. Moreover, the adequacy and rapid share of online resources give both the learners and their teachers with unequaled chances to gain knowledge and conduct online communication, which gives rise to the more involvement of the students in their the teaching process, foster students' innovative consciousness and contribute to the establishment of a new teacher-student relationship of equality and mutual assistance.

As suggestions for further research, it is also recommended that similar studies be conducted with a different and bigger sample. Besides reading comprehension other skills and components can be also taken into account. In order to come across with more credible data, further studies can be conducted in mixedmethods design in which the findings of the quantitative phase can be triangulated with those of qualitative phases.

\section{References}

1. Ary, D., Jacobs, C., \& Razavieh, A. (1990). Introduction to research in education. Fort Worth, TX: Holt, Rinehart and Winston, Inc.

2. Abraham, L.B. (2008). Computer-mediated glosses in second language reading comprehension and vocabulary learning: A meta-analysis. Computer Assisted Language Learning, 21 (3), 199-226.

3. Al-Busaidi, K. A., \& Al-Shihi, H. (2010). Instructors' acceptance of learning management systems: A theoretical framework. Communications of the IBIMA 2010, 1-10.

4. Ayan, E. (2015) Moodle as Builder of Motivation and Autonomy in English Courses. Open Journal of Modern Linguistics, 5, 6-20. doi: 10.4236/ojml.2015.51002.

5. Banditvilai, C. (2016). Enhancing students' language skills through blended learning. Electronic Journal of e- Learning, 14(3), 220-229. Retrieved 20
December

2016

from

http://files.eric.ed.gov/fulltext/EJ1107134.pdf.

6. Bataineh, R. F., \& Mayyas, M. B. (2017). The utility of blended learning in EFL reading and grammar: $A$ case for Moodle. Teaching English with Technology, 7 (3), 35-49 Retrieved 20 September 2017 from http://www.tewtjournal.org/?wpdmact=process \&did =NTAwLmhvdGxpbms.

7. Brandl, K. (2005). Are you ready to "Moodle"? Language Learning and Technology, 9 (2), 16-23.

8. Carey, S. (1999). The use of webCT for a highly interactive virtual graduate seminar. Computer Assisted Language Learning, 12, 371-380.

9. , A., Areal, N., \& Silva, J. (2011). Students' perceptions of blackboard and Moodle in a Portuguese university. British Journal of Educational Technology, 42 (5), 824-841.

10. Cole, J. (2005). Using Moodle: Teaching with the Popular Open Source Course Management System. US: O'Reilly Media, Inc.

11. Coskun, A., \& Arslan, A. (2014). Moodling English language education. Education, 134 (3), 275-281.

12. Davis, B. and R. Thiede (2000). Writing into Change: Style Shifting in Asynchronous Electronic Discourse, in M. Warschauer and R. Kern (eds), Network-based Language Teaching: Concepts and Practice, Cambridge: Cambridge University Press.

13. Dreyer, C., \& Nel, C. (2003). Teaching reading strategies and reading comprehension within a technology-enhanced learning environment. System, 31(3), 349-365.

14. Lambda Solutions (2017). The complete Moodle user guide. Retrieved 16 June 2017 from http://www.lambdasolutions.net/resources/thecomplete-Moodle-user-guidelan-introduction-toMoodle/.

15. Levy, M. (2009). Technologies in use for second language learning. The Modern Language Journal, 93 (1), 769-782.

16. Lin, L. (2009). Technology and second language learning. Retrieved 8 March 2017 from http://files.eric.ed.gov/fulltext/ED505762.pdf.

17. Mercer, N., L. Dawes, R. Wegerif, and C. Sams (2004) Reasoning as a scientist: ways of helping children to use language to learn science. British Educational Research Journal, 30 (3), 359-77.

18. Nation, P. (1990). Teaching and learning vocabulary. Boston: Heinle \& Heinle Publishers.

19. Pallant, J. (2007). SPSS survival manual: A stepby-step guide to data analysis using SPSS for Windows ( $3^{\text {rd }}$ ed.). McGraw Hill: Open University Press.

20. Plomteux, B. (2013). Moodle to the rescue to practice grammar in remediation classes. 
Proceedings of the Sixth International Conference: ICT for Language Learning (pp. 102-105). Florence, Italy: Libraria Universitaria.

21. Reinking, D., \& Rickman, S. S. (1990). The effects of computer-mediated texts on the vocabulary learning and comprehension of intermediate-grade readers. Journal of Reading Behavior, 22, 395-411.

22. Robb, T.N. (2004). Moodle: A virtual learning environment for the rest of Us. Teaching English as a Second or Foreign Language, 8 (2), 1-8.

23. Salaberry, M. R. (2001). The use of technology for second language learning and teaching: A retrospective. The Modern Language Journal, 85 (1), 39-56.

24. Sanprasert, N. (2009). The application of a course management system to enhance autonomy in learning English as a foreign language. System, 38 (1), 109-123.

25. Shudooh, Y. M. (2003). The application of computers in writing classes. (Doctoral Dissertation). University of Cincinnati. URL http://www.rave.ohiol ink.edu/etdc/view?acc_num= ucin 1053095635

26. Schunk, D. H. (2012). Learning theories: An educational perspective. Boston: Pearson.

27. Soliman, N. (2014). Using e-learning to develop EFL students' language skills and activate their indespendent learning. Creative Education, 5 (10), 1-5.

28. Sun, L. (2014). Investigating the effectiveness of Moodle-based blended learning in a college English course. International Journal of Information Technology and Management, 13 (1), 83-94.

29. Tsai, Y., \& Talley, P. (2014). The effect of a course management system (CMS)-supported strategy instruction on EFL reading comprehension and strategy use. Computer Assisted Language Learning, 27 (5), 422-438.

30. Winne, P.H., \& Hadwin, A.F. (1998). Studying as self-regulated learning. In D.J. Hacker, J. Dunlosky, \& A.C. Graesser (Eds.), Metacognition in educational theory and practice (2nd ed., pp. 277304). Mahwah, NJ: Lawrence Erlbaum Associates.

31. Wu, W. (2008). The application of Moodle on an EFL collegiate writing environment. Journal of Education and Foreign Languages and Literature, 7(1), 45-56.

32. Yang, Y., Gamble, J., Hung, Y., \& Lin, T. (2014). An online adaptive learning environment for critical thinking infused English literacy instruction. British Journal of Educational Technology, 45 (4), 723-747.

33. Zhang, L.J. (2008). Constructivist pedagogy in strategic reading instruction: Exploring pathways to learner development in the English as a second language (ESL) classroom. Instructional Science, 36, 89-116.
34. Zhao, Y. (2003). Recent developments in technology and language learning: A literature review and meta-analysis. CALICO Journal, 21 (1), 7-28.

35. Zhao, Y., \& Lai, C. (2008). Technology and second language learning: Promises and problems. In $L$. Parker (Ed.), Technology-mediated learning environments for young English learners: Connections in and out of school (pp. 167-205). New York Lawrence Erlbaum Associates. 